\title{
Nutritional Habits and Precocious Puberty in Girls: A Pilot Study
}

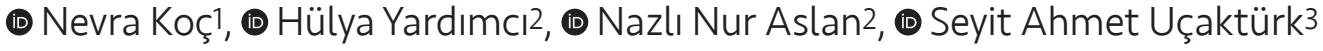 \\ 1University of Health Sciences, Ankara Child Health and Diseases Hematology Oncology Training and Research Hospital, Department of Pediatric \\ Nutrition and Metabolism, Ankara, Turkey \\ ${ }^{2}$ Ankara University Faculty of Health Sciences, Department of Nutrition and Dietetics, Ankara, Turkey \\ 3University of Health Sciences, Ankara Child Health and Diseases Hematology Oncology Research and Training Hospital, Department of Pediatric \\ Endocrinology, Ankara, Turkey
}

\begin{abstract}
Aim: Precocious puberty (PP) is defined as the appearance of secondary sexual characteristics before the age of nine in boys or eight in girls. Due to changing socio-economic conditions, nutritional habits and environmental factors, the onset of normal puberty is being seen at younger ages these days. The purpose of this study was to evaluate the dietary habits and environmental factors in cases that presented to or were being followed up by the Child Endocrinology Clinic with symptoms of PP.

Materials and Methods: The study group included 50 girls aged 2-8 years who presented with symptoms of PP and whose diagnosis was being monitored. A survey noting food consumption was made recording the girls' dietary habits, fast food consumption and frequency, information about their health, physical activity (PA) and environmental factors using a 24-hour-recall technique.

Results: The mean age of the girls was $7.1 \pm 0.9$ years. According to body mass index $z$-scores, $62.0 \%$ of the girls were overweight $[(\geq+1$ standard deviation (SD)], 34.0\% were normal ( $\geq+1$ SD $-<+1$ SD) and $4.0 \%$ were underweight. There was a statistically significant difference between the girls' levels of activity and their mean ages $(p<0.05)$. The girls' favorite choices of fast food were hamburgers $(20.3 \%)$, lahmacun (a thin pizza with spicy meat topping) (11.9\%), $32 \%$ of the girls were using perfumes or skin creams. Plastic culinary utensils were used in $56 \%$ of the children's homes. Of those girls who watched more than three hours of television (TV) a day, $71 \%$ were overweight.

Conclusion: Increased consumption of fast food containing higher amounts of fat, energy and protein in conjunction with decreased PA, exposure to chemicals that impair the endocrine system and exposure to stimulating devices (TV, computer) may be important factors in the development of PP. Further research is needed to evaluate the negative effects of these factors.

Keywords: Nutritional habits, menarche, obesity, precocious puberty, lifestyle
\end{abstract}

\section{Introduction}

Precocious puberty (PP) is defined as the early onset of puberty with the appearance of secondary sexual characteristics before nine years of age in boys and eight years of age in girls (1).

Paleontological data about the Neolithic age suggests that puberty occurred early in females. This was an evolutionary advantage given the short lifespan during that era, because they were able to reach reproductive capacity quickly. There was an increase in population density and deterioration in hygiene conditions in the period before the Industrial Revolution. This resulted in a delay in the age of menarche, which is the most prominent sign of puberty in females. During the years from the Industrial Revolution to the mid1900s, the menarche age started occurring earlier most likely due to improved environmental conditions, reduced rates of contagious diseases and easier access to food (2).

\section{Address for Correspondence}

Nevra Koç MD, University of Health Sciences, Ankara Child Health and Diseases Hematology Oncology Training and Research Hospital, Department of Pediatric Nutrition and Metabolism, Ankara, Turkey Phone: +90 5055025016 E-mail: nevrakoc@yahoo.com ORCID ID: orcid.org/0000-0002-4358-4443

Received: 13.03.2018 Accepted: 21.05.2018

${ }^{\circ}$ Copyright 2018 by Ege University Faculty of Medicine, Department of Pediatrics and Ege Children's Foundation The Journal of Pediatric Research, published by Galenos Publishing House. 
Herman-Giddens et al. (3) analyzed the results of a study performed by North Carolina University (Maternal and Child Health, Public Health School) using the Pediatric Research in Office Settings network and investigating the pubertal development of 17.077 girls between 3-12 years of age. A study in our country reported the prevalent rate of PP in girls between $4-8$ years of age was $4.3 \%$ (4). It was reported that breasts began to develop and pubic hair began to appear at earlier ages than reported in previous studies of American girls (10.0 years for Caucasian American girls and 8.9 years for Afro - American girls). However, the age of onset for menarche did not change (12.8 years and 12.1 years, respectively). Copenhagen Puberty Research reported a reduction in the age of puberty by up to 12 months in girls from Denmark (5). However, the hypotheses concerning the timing of adolescence are controversial with evidence suggesting that environmental factors play a role in the onset of puberty. Buck Louis et al. (6) reviewed the literature and defined environment as "the sum of all external factors that affect the life, development and survival of an organism". A more extended definition describes environmental factors as non-inheritable factors. Current studies focus on body measurements, nutritional habits and duration of exposure to endocrine impairing chemicals that affect the timing of puberty (7).

Diet is one of the most important factors affecting pubertal development. An adequate, balanced and healthy diet is necessary for all stages of growth and for normal pubertal development. Excessive consumption of processed, high-energy and high-fat food can lead to obesity and PP. Overweight and obese children enter puberty at earlier ages (8).

The aim of this study is to identify the food-related and environmental risk factors that affect the development of PP and to determine their relationship with nutrition in girls that presented to the child endocrinology clinic with signs of PP or who were previously diagnosed with PP and are being monitored.

\section{Materials and Methods}

\section{Plan and Methods}

\section{Place of Study and Sample Selection}

This study included 50 girls aged 2-8 years who presented to the University of Health Sciences, Ankara Child Health and Diseases Hematology Oncology Research and Training Hospital, Department of Pediatric Endocrinology with signs of PP or who had previously been diagnosed with PP. Approval was obtained from the Local Ethics Committee (approval no: 2017/095).

\section{Data Collection}

Data for the study group was collected using a structured questionnaire. The questionnaires were filled in by the researcher during one-on-one interviews with the children's parents. The questionnaire provided information about the children's demographic characteristics, their nutritional habits (skipping meals and the reasons for this, consumption of fast food and how often, their most preferred food), information about their health status, and daily food consumption using a 24-hour-recall technique.

\section{Assessment of Dietary Intake and Frequency of Fast Food Consumption}

A photographic atlas of food portion sizes was used as a reference in creating a food consumption record using the 24-hour-recall technique in order to determine the girls' nutritional status and their daily levels of energy intake and food consumption (9). Using the 24-hour-recall method, their parents were asked to write down on pre-prepared forms all the food consumed by their daughters over the previous 24 hours.

The frequency table for daily food consumption and fast food consumption recorded the frequency at which the girls consumed food and beverages as follows: daily, 5-6 days a week, 3-4 days a week, 1-2 days a week, once every two weeks, once a month, infrequently and never.

\section{Anthropometric Measurements}

The girls' height $(\mathrm{cm})$, weight $(\mathrm{kg})$, waist circumference $(\mathrm{cm})$, upper mid-arm circumference $(\mathrm{cm})$ and skin fold thickness $(\mathrm{mm})$ were measured and recorded on the Anthropometric Measurements Record Form. The anthropometric measurements were taken in the morning while fasting after the girls' shoes and outer clothing were removed. Body weights were measured using SECA brand scales and recorded in kilograms. Height measurements were made with the help of a portable height measuring bar while the girls stood against a wall with their feet together and their heads oriented in the Frankfort plane (eye triangle and ear auricle aligned parallel to the ground). The body mass index (BMI) z-scores determined by age and gender were calculated with the World Health Organization Anthroplus program using the data obtained from the girls' body mass and height measurements. Those who rated +1 SD to +2 SD were considered "slightly overweight" while those rated +2 SD to +3 SD were considered "overweight" and those of +3 SD or higher were considered "extremely overweight" (10). Consent form was filled out by all participants.

\section{Statistical Analysis}

The data obtained using the questionnaire were analyzed using the SPSS package program. The food consumption data obtained using the 24-hour-recall method were broken down into nutrient content values using standard meal recipes. 
The average daily nutrient amounts per individual were entered into the BEBIS program (11) in order to determine the daily consumption of energy and nutrients. The data obtained were evaluated with respect to the Recommended Dietary Allowances (RDA) (12,13). The intersection points in the evaluation were calculated as recommended daily intake levels $[(2 / 3=67 \%) \pm 33 \%]$. Consumption of energy and nutrients at $67-133 \%$ of RDA was accepted as adequate, $<67 \%$ was accepted as inadequate and $>133 \%$ as high. The Student's t-test was used to compare the means between the normally distributed variables in two groups, while the one-way ANOVA test was used to compare the normally distributed variables between three or more groups. Statistical analyses were evaluated at $95 \%$ confidence value with $p<0.05$ being considered significant.

\section{Results}

This study included 50 girls aged 2-8 years who presented to the University of Health Sciences, Ankara Child Health and Diseases Hematology Oncology Research and Training Hospital, Department of Pediatric Endocrinology with PP symptoms or who had previously received a PP diagnosis. The mean age of the girls was $7.1 \pm 0.9$ years. There was a significant difference in mean age of the girls in relation to their mothers' education levels $(p<0.05)$.

According to $\mathrm{BMI} z$ scores, $62.0 \%$ of the children were overweight ( $\geq+1$ SD), $34.0 \%$ were normal $(\geq+1$ SD $-<+1$ SD) and $4.0 \%$ were underweight. In percentile terms $60.0 \%$ were overweight ( $\geq 85^{\text {th }}$ percentile), $36.0 \%$ were normal $\left(\geq 15^{\text {th }}-<85^{\text {th }}\right.$ percentile $)$ and $4.0 \%$ were underweight $\left(<15^{\text {th }}\right.$ percentile) (Table I).

In this study, $82 \%$ of girls with signs or symptoms of PP or who had been given a PP diagnosis reported that they did not engage in any regular physical activity (PA). The girls engaging in regular PA was $18 \%$ which percentage engaged in daily PA was 33.3\% and engaged in regular PA 3-4 days a week was $66.7 \%$. Activity was seen to decrease as age increased $(p<0.05)$.

When the girls' meal arrangements are examined, it can be seen that $84.0 \%$ consume three main meals and three snacks every day, $92.0 \%$ do not eat at night while $60.0 \%$ eat a final meal/snack between 8.00 and 10.00 p.m. It was determined that $58.0 \%$ of the children eat their lunch in

\begin{tabular}{|l|l|l|}
\hline Table I. Body mass index z-score of the girls & S & $\%$ \\
\hline z score and percentiles & 2 & 4.0 \\
\hline z score & 17 & 34.0 \\
\hline Underweight (<-1 SD) & 31 & 62.0 \\
\hline Normal ( $\geq-1$ SD - <+1 SD) &
\end{tabular}

SD: Standard deviation
20-30 minutes. Body weight was reported as having increased $(64 \%)$, decreased $(6 \%)$ or remained unchanged $(30 \%)$ over the previous six months.

Some characteristics of the girls with regard to fast food consumption are given in Table II.

$64.0 \%$ of the girls consumed fast food infrequently, $20.0 \%$ consumed fast food $1-2$ days per week, $4.0 \%$ consumed fast food every day and $12.0 \%$ never consumed any fast food.

The fast food types most preferred by the girls are shown in Table III.

According to this, hamburgers (20.3\%), pita-lahmacun $(11.9 \%)$ and grilled chicken in bread (11.3\%) were the top three favorite fast foods.

When the energy and nutrients that the girls receive daily are examined according to the reference intervals, it can be seen that $74.0 \%$ receive sufficient energy and their intake of carbohydrates $(66.0 \%)$, calcium (48.0\%), folate $(58.0 \%)$ and vitamin $\mathrm{B}_{6}(46.0 \%)$ are also sufficient. Their dietary intake of protein (68.0\%), vitamin A (50.0\%), vitamin C (44.0\%) and vitamin $\mathrm{B}_{12}(52.0 \%)$ are higher than recommended. Iron intake was found to be insufficient in $54.0 \%$ of the girls (Table IV).

An examination of other environmental factors that might be instrumental in the development of PP revealed that $32.0 \%$ of the girls used perfumes or skin creams. Plastic culinary utensils were used in $56.0 \%$ of their homes, $64 \%$ of them had a cigarette smoker at home, while some mothers consumed cigarettes (16\%) and alcohol (2\%) during pregnancy. Analysis of the time spent in front of the television (TV) revealed that the overweight girls watched TV

\begin{tabular}{|l|l|l|}
\hline $\begin{array}{l}\text { Table II. Fast food consumption frequency, menu and beverage } \\
\text { choices of the girls }\end{array}$ & \multicolumn{1}{l|}{ S } & $\%$ \\
\hline Fast food consumption characteristics & 2 & 4.0 \\
\hline Frequency (n=50) & 10 & 20.0 \\
\hline Everyday & 32 & 64.0 \\
\hline Once or twice a week & 32 & 12.0 \\
\hline Rarely & 6 & \\
\hline Never & \multicolumn{2}{|l|}{} \\
\hline Preferences of fast food menu & 18 & 36.0 \\
\hline Standard menu & 32 & 64.0 \\
\hline One by one select & \multicolumn{2}{|l|}{} \\
\hline If the preference is standard menu, selected beverages are... (n=18) \\
\hline Cola & 7 & 38.9 \\
\hline Diet Cola & - & - \\
\hline Yogurt drink/Ayran & 8 & 44.4 \\
\hline Packed fruit juice & 2 & 11.1 \\
\hline Freshly squeezed fruit juice & 1 & 5.6 \\
\hline Carbonated beverage & - & - \\
\hline
\end{tabular}


for less than an hour a day (76.9\%), 2-3 hours a day (11.7\%) and 3-4 hours a day (11.2\%) with no statistical difference found between them $(p>0.05)$. It was determined that they watched TV mostly at night and that most of them watched TV series.

\section{Discussion}

The age at which puberty begins varies depending on

\begin{tabular}{|l|l|l|}
\hline \multicolumn{3}{|l|}{ Table III. The most preferred fast food for girls } \\
\hline The most rated fast food & S & $\%$ \\
\hline Hamburger & 65 & 20.3 \\
\hline Lahmacun-Pide & 38 & 11.9 \\
\hline Chicken döner kebab & 36 & 11.3 \\
\hline Pizza & 30 & 9.4 \\
\hline Meat döner kebab & 25 & 7.8 \\
\hline Toast & 23 & 7.2 \\
\hline Turkish bagels & 23 & 7.2 \\
\hline Pastries & 19 & 5.9 \\
\hline Fried potatoes & 18 & 5.6 \\
\hline Shish kebab & 15 & 4.7 \\
\hline Baked potato & 8 & 2.5 \\
\hline Kebab & 6 & 1.9 \\
\hline Turkish pancake & 4 & 1.3 \\
\hline Chicken sandwich & 3 & 0.9 \\
\hline Salad bar & 3 & 0.9 \\
\hline Sandwich & 3 & 0.9 \\
\hline Chicken shish & 1 & 0.3 \\
\hline
\end{tabular}

Table IV. Comparison of energy and nutrient intake of girls by reference intervals

\begin{tabular}{|l|l|l|l|l|l|l|}
\hline \multirow{2}{*}{$\begin{array}{l}\text { Energy and } \\
\text { nutrients }\end{array}$} & \multicolumn{2}{l|}{$\begin{array}{l}\text { Deficient } \\
(<\mathbf{6 7 \% )}\end{array}$} & \multicolumn{2}{l|}{$\begin{array}{l}\text { Adequate } \\
\mathbf{( 6 7 - 1 3 3 \% )}\end{array}$} & \multicolumn{2}{l|}{$\begin{array}{l}\text { Excess } \\
(<133 \%)\end{array}$} \\
\cline { 2 - 8 } & $\mathbf{S}$ & $\%$ & $\mathbf{S}$ & $\%$ & $\mathbf{S}$ & $\%$ \\
\hline Energy & 12 & 24.0 & 37 & 74.0 & 1 & 2.0 \\
\hline Carbohydrate & 5 & 10.0 & 33 & 66.0 & 12 & 24.0 \\
\hline Protein & 2 & 4.0 & 14 & 28.0 & 34 & 68.0 \\
\hline Calcium & 19 & 38.0 & 24 & 48.0 & 7 & 14.0 \\
\hline Iron & 27 & 54.0 & 22 & 44.0 & 1 & 2.0 \\
\hline A vitamin & 10 & 20.0 & 15 & 30.0 & 25 & 50.0 \\
\hline C vitamin & 15 & 30.0 & 13 & 26.0 & 22 & 44.0 \\
\hline Folate & 12 & 24.0 & 29 & 58.0 & 9 & 18.0 \\
\hline$B_{6}$ vitamin & 7 & 14.0 & 23 & 46.0 & 20 & 40.0 \\
\hline$B_{12}$ vitamin & 11 & 22.0 & 13 & 26.0 & 26 & 52.0 \\
\hline
\end{tabular}

genetic features, nutritional status, obesity, stress and environmental factors (14). Signs of puberty are manifesting earlier in children these days and the number of patients presenting to endocrinology clinics due to and diagnosed with PP has also increased. The aim of this study was to identify the nutritional and environmental risk factors affecting PP and to determine if there was any relationship between nutritional habits and children who presented to pediatric endocrinology clinics with signs and symptoms of PP or who had been previously diagnosed with PP.

Puberty refers to a developmental period of rapid and profound change (15). Clinically speaking, puberty in girls is defined as the first appearance of the mammary buds (16). PP is defined as the appearance of secondary sexual characteristics in girls before eight years of age (17). This study included 50 girls aged 2-8 who presented with signs or symptoms of PP or who had previously been diagnosed with PP. Their mean age was $7.1 \pm 0.9$ years. The mean age of the children increased significantly as the education level of their mothers increased $(p<0.05)$.

The normal age range for the onset of puberty in girls was 8-13 according to cross-sectional data in the 1960s. In Turkish society, the age of onset of puberty was reported to be $10.1 \pm 1.0$ years for girls (18). Cross sectional data obtained in the United States (US) and Europe in the last two decades report that pubertal milestones are being reached earlier in both sexes (3,19-21).

The signs of PP are advanced bone age, accelerated growth and increased body weight (22). Some modifiable factors such as dietary habits and high adiposity play important roles in the development of PP (23-25). Accordingly, going by their BMI z-scores, $(\geq+1$ SD) $62.0 \%$ of the girls were overweight [60\% according to percentile values ( $\geq 85^{\text {th }}$ percentile)]. A childhood obesity study in our country (26) showed that $21.2 \%$ of children aged $7-8$ were overweight-obese according to BMI $z$-scores. This suggests that girls in our country are in a risk group for PP.

Girls and boys who take part in intense PA and exercise were found to have lower $\mathrm{BMI}$ and body fat percentage values and later onset of puberty (27). A study involving 3.206 subjects in Colombia detected that menarche age was delayed in girls who perform PA for two hours or more a day (28). In this study, only $18 \%$ of the girls with PP were reported as undertaking regular PA. Promoting PA for children with the goal of establishing it as a lifestyle is very important for their general health, psychological status and socializing skills. Specifically, increasing the number of hours for physical education in schools and using these hours actively may help to decrease obesity.

Nutrition is an important factor affecting the timing of puberty. While no single factor is thought to be solely effective, it is believed that the presence of multiple factors can influence the timing of puberty (29). Excessive nutrition 
and obesity are thought to trigger the onset of puberty. Nutritional status during childhood is thought to be $25 \%$ responsible for the early onset of puberty (30). The data obtained during this study from the girls with signs and symptoms of PP and girls who had PP diagnosis showed that $84 \%$ regularly consumed three main meals and three snacks a day. Ashwell (31) reported that $13.6 \%$ of the girls between 6-11 years of age did not eat breakfast. In this study, only $3 \%$ skipped breakfast because they did not want to have breakfast. In fact, a good breakfast reduces the consumption of snacks and energy rich food and therefore helps to manage the body weight of girls with PP who are undergoing treatment.

It takes 20 minutes for the body to feel sated. Therefore, when food is eaten quickly more food is consumed during this time $(32,33)$. In this study, $58.0 \%$ of girls took $20-30$ minutes to eat their meals. This could create a negative situation in that too much food could be eaten during this time.

It is reported that inadequate and unbalanced nutrition, processed foods and the consumption of foods with high fat and sugar contents may be the cause of the increased incidence in childhood obesity recently and the early onset of puberty in girls (34). One study demonstrated that children are encouraged to consume cheap, easily available snacks that have high energy density and low nutrient values, and that this puts children at risk of early puberty (35). In this study, $20 \%$ of the girls with the signs and symptoms of PP or with a PP diagnosis consumed fast food one or two days a week and 64\% consumed fast food infrequently (Table II). The most commonly preferred fast foods by the girls were high energy foods such as hamburger (20.3\%), lahmacun (11.9\%), chicken doner kebab (11.3\%), pizza (9.4\%), meat doner kebab (7.8\%), grilled toast and melted cheese (7.2\%), bread rings $(7.2 \%)$, pastries $(5.9 \%)$, french fries $(5.6 \%)$ and shish kebab (4.7\%) (Table III).

There is evidence to suggest that the consumption of animal proteins during childhood may be related to PP. A study of children aged 3-8 years in the US found correlations between the consumption of whole animal proteins and early menarche and Age of Peak Height Velocity (APHV) (36). In another study, the consumption of whole and animal-derived protein by 112 boys and girls aged 5-6 years was associated with menarche in girls and voice change in boys. That same study found a link between protein from cow's milk and other dairy products and early pubertal growth and APHV (37). While some studies have suggested a link between animalderived protein sources and early sexual development, other studies have reported a link between the consumption of plant-based protein sources in childhood and the late onset of puberty. For example, analyses in a study made by Dortmund Nutritional and Anthropometric Longitudinal Design showed that children whose plant-based protein intake was in the lowest one third had earlier APHV than children whose intake was in the highest one third (37). Similarly, Berkey et al. (36) demonstrated a positive correlation between plant-based protein intake and menarche and APHV. The girls in this study consumed a mean of $50.9 \pm 20.4 \mathrm{~g}$ total protein, $33 \pm 18.9 \mathrm{~g}$ animal protein and $17.9 \pm 6.8 \mathrm{~g}$ plant-based protein daily with diet. The mean protein percentage of the daily diet is $15.2 \pm 4.1$. $68 \%$ of the girls consumed more than the required amount of protein and $28 \%$ consumed sufficient amounts of protein. The girls' protein consumption was slightly higher than the recommended limits. The interaction with PP may be due to micronutrients, mycotoxins or drugs in the feed given to the animals that provide the protein source.

Previous research on dietary fat and the age of menarche reported a positive relationship between the consumption of fat containing polyunsaturated fatty acids and early menarche and a negative relationship between the consumption of fat containing saturated fatty acids and early menarche $(36,38,39)$. The mean daily fat consumption of the girls in this study was $61.9 \pm 21.7 \mathrm{~g}$ with $40.1 \pm 8.4 \mathrm{~g}$ of daily energy being derived from fat. In this study, the percentage of fat-derived energy in daily energy intake was high. It is important that mono and polyunsaturated fats instead of saturated fats are promoted and that they are consumed at the recommended levels. This may prevent both obesity and other health problems associated with obesity.

Kissinger and Sanchez (40) found a positive and statistically significant relationship between iron intake and the age of menarche in 230 girls in the US. Maclure et al. (38) demonstrated that in children with sufficient total energy intake, an increase in vitamin A intake had a strong association with early menarche. In this study, the girls' average daily calcium intake was $634.2 \pm 319.2$, iron intake was $7.3 \pm 2.7 \mathrm{mg}$ and vitamin A intake was 1.080.6 \pm 1.829 .9$ mg. A randomized study of 144 Swiss girls reported that girls who received calcium supplements between 7.9-8.9 years of age reached menarche earlier than girls who did not receive calcium supplements (41). In our study, $48.0 \%$ of the girls received adequate amounts of calcium, 54\% received inadequate amounts of iron and 50\% received excessive amounts of vitamin A. Animal-derived protein sources should be promoted in order to increase children's iron intake while milk and dairy products should be promoted in order to increase calcium intake.

Bisphenol A (BPA), an estrogenic compound used in food and beverage packaging, has been associated with late puberty in several studies. Phthalates, which are used for food packaging, have been associated with early menarche in girls (42). An analysis of 2003-2010 National Health and Nutrition Examination Survey data on 987 adolescent girls aged 12-19 years found that girls with moderate BPA levels were less likely to experience early menarche than girls with low BPA levels. They suggested that BMI may have changed the relationship between menarche and BPA (43). A 
cross-sectional study investigated the associations between exposure to phthalate and sexual maturation in 725 girls aged 6-19 years in Denmark. The researchers found that the girls in the highest quarter for exposure to mono-n-butyl phthalate + mono-isobutyl phthalate and monobenzyl phthalate reached stage 2 of pubic hair development at a later age than girls in the lower quarters (44).

In this study, $56 \%$ of their parents reported using plastic culinary utensils at home. $60.0 \%$ of the children drink water out of plastic bottles, $6.0 \%$ rarely do so and $34.0 \%$ do not. $70.0 \%$ of the families used plastic bottles/jugs for water consumption. Most of the families used high amounts of plastic products and packaged products. An analysis of the consumption of snack foods revealed that $98 \%$ of the girls did not consume these products. These endocrine spoilers stimulate the hypothalamo-hypophyseal-gonadal axis and cause shifts in the age of puberty. For this reason, parents should be informed about this topic. In short, we suggest that materials used for food packaging should be health-friendly and should not cause health problems.

Time spent in front of visual media like TV, computers, tablets etc. is an important risk factor for obesity. Also, the visual and sexual content of the programs watched may accelerate the puberty process and may cause emotional confusion with respect to sexuality (45). Analysis of the time spent in front of the TV revealed that the overweight girls watched TV for less than an hour a day (76.9\%), 2-3 hours a day $(11.7 \%)$ and $3-4$ hours a day $(11.2 \%)$ with no statistical difference found between them ( $p>0.05)$.

\section{Study Limitations}

The small number of subjects due to the limited time period is one of the factors that limited our work. Moreover, the use of a control group in addition to a study group would have made the study's results more significant and accurate. In order for future studies examining the effects of nutrition on puberty to give more significant results, study groups should be divided into newly diagnosed patients and followup patients because once diagnosis has been made, the families' awareness increases resulting in changes to their children's dietary habits.

\section{Conclusion}

Changing lifestyles and habits in all aspects of society have led to an increase in the number of children with PP. In girls with PP, particularly when they are treated for more than a year, the importance of maintaining the ideal bodyweight should be emphasized. Consistent nutritional training, methods to increase the intensity and duration of PA and maintaining regular meal times are important factors in the dietary management of obesity. Physicians should monitor these children regularly and give nutritional counseling. Since children use their parents as role models, the girls' nutritional habits are also similar to their parents' habits. In order to advance the age of puberty, families should be educated about their children's nutritional habits and PA status. Advising girls with PP to modify their eating habits such as having breakfast, eating less food at mealtimes and eating more slowly is important in that it prevents obesity by promoting healthy eating habits.

Further research with a larger cohort is required to determine the effects of nutrition on puberty.

\section{Ethics}

Ethics Committee Approval: The study was approved by the University of Health Sciences Ankara Child's Health and Diseases Hematology Oncology Training and Research Hospital Local Ethics Committee (approval number: 2017/095).

Informed Consent: Consent form was filled out by all participants.

Peer-review: Externally and internally peer-reviewed.

\section{Authorship Contributions}

Surgical and Medical Practices: N.K., S.A.U., Concept: N.K., H.Y., Design: N.K., H.Y., N.N.A Data Collection or Processing: N.K., S.A.U., N.N.A Analysis or Interpretation: N.K., H.Y., N.N.A., Literature Search: N.K., N.N.A, H.Y. Writing: N.N.A, H.Y, S.A.U.

Conflict of Interest: No conflict of interest was declared by the authors.

Financial Disclosure: The authors declared that this study received no financial support.

\section{References}

1. Carel JC, Lahlou N, Roger M, Chaussaın JL. Precocious puberty and statural growth. Hum Reprod Update 2004;10:135-47.

2. Gluckman PD, Bergstrom CT. Christmas 2011: Food for Thought: Evolutionary biology with in medicine: a perspective of growing value. BMJ 2011;343:4-8.

3. Herman-Giddens ME, Slora EJ, Wasserman RC, et al. Secondary sexual characteristics and menses in young girls seen in office practice: a study from the Pediatric Research in Office Settings network. Pediatrics 1997;99:505-12.

4. Atay Z, Turan S, Guran T, Furman A, Bereket A. The prevalence and risk factors of premature thelarche and pubarche in 4 to 8 year old girls. Acta Paediatr 2012;10:71-5.

5. Aksglaede L, Sorensen K, Petersen JH, Skakkebæk NE, Juul A. Recent decline in age at breast development: the Copenhagen Puberty Study. Pediatrics 2009;123:932-9.

6. Buck Louis GM, Gray LE Jr, Marcus M, et al. Environmental factors and puberty timing: expert panel research needs. Pediatrics 2008;121(Suppl 3):192-207.

7. Euling SY, Herman-Giddens ME, Lee PA, et al. Examination of US puberty-timing data from 1940 to 1994 for secular trends: panel findings. Pediatrics 2008;121(Suppl 3):172-91. 
8. Soliman A, De Sanctis $V$, Elalaily R. Nutrition and Pubertal Development. Indian J Endocrinol Metab 2014;18(Suppl 1):39-47.

9. Rakicioglu N, Tek Acar N, Ayaz A, et al. Yemek ve besin fotoğraf kataloğu ölçü ve miktarlar. Hacettepe Üniversitesi Beslenme ve Diyetetik Bölümü. Ankara, Ata Ofset Matbaacılık, 2015

10. World Health Organization. 2013. Obesity. http://www.who. int/topics/obesity/en/.

11. BEBiS. Bebis Nutrition Data Base. The German Food Code and Nutrient Data Base (BLS II.3, 1999) with additions from USDA-sr and other sources, İstanbul, Turkey, 2004.

12. NAP. National Academy Press. Nutrient Adeqency-Asessment Using Food Consumption Surveys. Washington D.C, 1986:14.

13. Pekcan G. Beslenme durumunun saptanması. T.C. Sağlık Bakanlığı Temel Sağlık Hizmetleri Genel Müdürlüğü Beslenme ve Fiziksel Aktiviteler Daire Başkanlığı, Sağlık Bakanlığı. Ankara, Klasmat Matbaacılık, 2008.

14. Kletter $\mathrm{CB}$, Klein $\mathrm{KO}$, Wong YY. A pediatrician's guide to central precocious puberty. Clin Pediatr (Phila) 2015;54:414-24.

15. Golub MS, Collman GW, Foster PM, et al. Public health implications of altered puberty timing. Pediatrics 2008;121:21830.

16. Parent AS, Teilmann G, Juul A, Skakkebaek NE, Toppari J, Bourguignon JP. The timing of normal puberty and the age limits of sexual precocity: variations around the world, secular trends, and changes after migration. Endocr Rev 2003;24:668-93.

17. Carel JC, Leger J. Precocious puberty. N Engl J Med 2008;358:236677.

18. Bundak R, Darendeliler F, Günöz H, Baş F, Saka N, Neyzi O. Puberty and pubertal growth in healthy Turkish girls: no evidence for secular trend. / Clin Res Pediatr Endocrinol 2008;1:8-14.

19. Aksglaede L, Sorensen K, Petersen JH, Skakkebæk NE, Juul A. Recent decline in age at breast development: the Copenhagen Puberty Study. Pediatrics 2009;123:932-9.

20. Roelants M, Hauspie R, Hoppenbrouwers K. References for growth and pubertal development from birth to 21 years in Flanders, Belgium. Ann Hum Biol 2009;36:680-94.

21. Biro FM, Greenspan LC, Galvez MP, et al. Onset of breast development in a longitudinal cohort. Pediatrics 2013;132:1019-27.

22. Çatlı G, Erdem P, Anık A, Abacı A, Böber E. Clinical and laboratory findings in the differential diagnosis of central precocious puberty and premature thelarche. Turk Pediatri Ars 2015;50:20-6

23. Maisonet $M$, Christensen $K Y$, Rubin $C$, et al. Role of prenatal characteristics and early growth on pubertal attainment of British girls. Pediatrics 2010;126:591-600.

24. Cheng G, Buyken AE, Shii L, et al. Beyond overweight: nutrition as an important lifestyle factor influencing timing of puberty. Nutr Rev 2012;70:133-52.

25. Salgin B, Norris SA, Prentice $P$, et al. Even transient rapid infancy weight gain is associated with higher BMI in young adults and earlier menarche. Int J Obes (Lond) 2015;39:939-44.

26. Çocukluk Çağı Obezite Araştırması-2013 (COSI-TR-2013). Erişim adresi: http://www.diabetcemiyeti.org/var/cdn/a/f/cosi-trsonuclari.pdf
27. Buchan DS, Ollis S, Young JD, et al. The effects of time and intensity of exercise on novel and established markers of CVD in adolescent youth. Am J Hum Biol 2011;23:517-26.

28. Chavarro J, Villamor E, Narvaez I, Hoyos A. Socio-demographic predictors of age at menarche in a group of Colombian university women. Ann Hum Biol 2004;31:245-57.

29. Fisher MM, Eugster EA. What is in our environment that effects puberty? Reprod Toxicol 2014;44:7-14.

30. Karlberg J. Secular trends in pubertal development. Horm Res $r$ 2002;57(Suppl 2):19-30.

31. Ashwell M. An examination of the relationship between breakfast, weight and shape. Br I Nurs 2010;19:1155-9.

32. Cho KY, Park H, Seo JW. The relationship between lifestyle and metabolic syndrome in obese children and adolescents. Korean J Pediatr Gastroenterol Nutr 2008;11:150-9.

33. Hassink SG; Pediatric Expert Panel. Weighing risk: the expert committee's recommendations in practice. Semin Pediatr Surg 2009;18:159-67.

34. Proos L, Gustafsson I. Is early puberty triggered by catch-up growth following undernutrition? Int J Environ Res Public Health 2012;9:1791-809.

35. Moffat T. The "childhood obesity epidemic": health crisis or social construction?. Med Anthropol Q 2010;24:1-21.

36. Berkey CS, Gardner JD, Frazier AL, Colditz GA. Relation of childhood diet and body size to menarche and adolescent growth in girls. Am J Epidemiol 2000;152:446-52.

37. Günther AL, Karaolis-Danckert N, Kroke A, Remer T, Buyken AE. Dietary protein intake throughout childhood is associated with the timing of puberty. I Nutr 2010;140:565-71.

38. Maclure M, Travis LB, Willett W, Macmahon B. A prospective cohort study of nutrient intake and age at menarche. Am J Clin Nutr 1991;54:649-56.

39. Rogers IS, Northstone K, Dunger DB, Cooper AR, Ness AR, Emmett PM. Diet throughout childhood and age at menarche in a contemporary cohort of British girls. Public Health Nutr 2010;13:2052-63.

40. Kissinger DG, Sanchez A. The association of dietary factors with age at menarche. Nutr Res 1987;7:471-9.

41. Chevalley T, Rizzoli R, Hans D, Ferrari S, Bonjour JP. Interaction between calcium intake and menarcheal age on bone mass gain: an eight-year follow-up study from prepuberty to postmenarche. J Clin Endocrinol Metab 2005;90:44-51.

42. Zhang Y, Cao Y, Shi H, et al. Could exposure to phthalates speed up or delay pubertal onset and development? A1.5-year followup of a school-based population. Environ Int 2015;83:41-9.

43. Mcguinn LA, Ghazarian AA, Joseph Su L, Ellison GL. Urinary bisphenol $A$ and age at menarche among adolescent girls: evidence from NHANES 2003-2010. Environ Res 2015;136:381-6.

44. Frederiksen $H$, Sorensen $K$, Mouritsen $A$, et al. High urinary phthalate concentration associated with delayed pubarche in girls. Int I Androl 2012;35:216-26.

45. Brown JD, Halpern CT, L'Engle KL. Mass media as a sexual super peer for early maturing girls. I Adolesc Health 2005;36:420-7. 